\title{
Daily activity and flight behaviour of adults of Capnodis tenebrionis (Coleoptera: Buprestidae)
}

\author{
Carmelo Peter BONSignORE ${ }^{1}$ and Charlie BELlamy ${ }^{2}$ \\ ${ }^{1}$ Department of Territorial and Environmental Science, Mediterranean University, Salita Melissari - Feo de Vito, 89124 Reggio
Calabria, Italy; e-mail: cbonsignore@unirc.it \\ ${ }^{2}$ Plant Pest Diagnostics - California Department of Food \& Agriculture, 3294 Meadowview Road, Sacramento, CA 95832-1448, \\ USA; e-mail: cbellamy@cdfa.ca.gov
}

Key words. Buprestidae, Capnodis tenebrionis, flight activity, feeding activity, insect movement

\begin{abstract}
Ecological studies on the buprestid beetle Capnodis tenebrionis (Linnaeus, 1767) were carried out in the laboratory and the field. In particular, attention focussed on the effects of seven different temperatures at different times during the day on the movement and feeding activity of this beetle. Field experiments in an apricot orchard recorded the flight activity of $C$. tenebrionis, with particular reference to the effect of temperature and wind. The experiments highlighted the marked response of movement, feeding and flight activity to increase in temperature. The optimal temperature for feeding, movement and flight was $30^{\circ} \mathrm{C}$ and above with negative effects occurring at $45^{\circ} \mathrm{C}$. Flight generally occurred in the middle of the day. Wind had a negative effect on flight activity. Wind speeds in excess of $4 \mathrm{~m} / \mathrm{s}$ prevented the insect from taking off. The spread of this phytophagous beetle from one orchard to another is unquestionably influenced by the daily activity and flight behaviour of the adult.
\end{abstract}

\section{INTRODUCTION}

Capnodis tenebrionis (Linnaeus, 1767) (Coleoptera: Buprestidae) is highly destructive in orchards of drupaceous fruit trees, in particular species of plums (Garrido, 1984; Martin et al., 1998; Ben Yehuda et al., 2000). In the Mediterranean region, it is becoming increasingly widespread and is particularly damaging in organic orchards where plants are rapidly killed by the destructive activity of larvae, which attack the neck and roots of the plants. The adult beetles feed on the young bark of shoots, buds and above all at the base of the petioles of leaves, which drop off and form a layer of leaves under the trees, which reveal the presence of the insect.

At present, it is very difficult to control C. tenebrionis infestations and it has no known effective natural enemies (Marannino \& de Lillo, 2005). Chemical intervention against larvae in infested plants has little effect, especially when the host plants are adult trees. Only the treatment of the ground in young plantations and nurseries with systemic insecticides is successful in protecting saplings against root infestations and rendering the foliage toxic to adult beetles (Ben Yehuda et al., 2000). Currently there are no methods for protecting arboreal production against this pest. In addition, there are few methods of monitoring Buprestidae (Dunn et al., 1986) as traps provide erratic and variable information on the flight periodicity and the species present, and are therefore of little help in controlling the beetles (Atkinson et al., 1988; Markalas \& Kalapanida, 1997; Fassotte, 1999; Morewood et al., 2002; Groot \& Nott, 2003; Oliver et al., 2003; Miller, 2006).

Dispersal in C. tenebrionis, as in other winged insects, besides mechanisms linked to human activity, is mainly dependent on long distance flights (Duan et al., 1998;
Muirhead et al., 2006). Understanding flight characteristics might provide useful information for controlling the further spread of this pest.

Flight is influenced by atmospheric factors such as wind, air temperature and rainfall (Isard et al., 1999; Elliot et al., 2000) as well as biological, genetic, physiological and enzymatic factors (Ferro et al., 1999; PerezMendoza et al., 1999; Zera et al., 1999; Auerswald \& Gäde, 2002). Furthermore, physical factors such as infrared radiation can influence the flight performance of some insects. Species of Coleoptera, like Melanophila acuminata De Geer, Merimna atrata (Laporte \& Gory) (Buprestidae) and Acanthocnemus nigricans (Hope) (Acanthocnemidae), endowed with IR receptor organs, use IR to correct flight direction in order to locate forest fires (Evans, 1966; Schmitz \& Bleckmann, 1998; Schmitz et al., 2000, 2002).

It proved easy to analyse the flight activity of $C$. tenebrionis as it is big and stocky and flies with a distinctive loud buzz. The only problem was locating adults about to take off. There are no studies on the importance of flight in the spread of this insect, which is thought to be dispersed mainly via infected plants containing the larval stages of the insect.

A better understanding of the ecology of $C$. tenebrionis is necessary for developing techniques to prevent the spread of this insect from one orchard to another.

The present paper, as well as highlighting the effect of temperature, time and sex on the feeding and movement of the adult insect (laboratory experiments), aims to illustrate the effect of a number of factors on flight performance (field experiment) and provides further insights into the population ecology of $C$. tenebrionis. 


\section{MATERIAL AND METHODS}

\section{Laboratory experiment}

Laboratory observations were carried out inside a climatic chamber containing plexiglass cages. Each cage had two separate compartments measuring $25 \times 25 \times 35 \mathrm{~cm}$. An apricot shoot with at least 12 leaves was placed in the middle of each cage. The base of each shoot was placed inside a plastic tube containing water. Twelve hours before the observations began, one pair of adults (male and female) was placed in each cage. The adults had overwintered and were collected in an aprico orchard in Sicily $\left(37^{\circ} 25^{\prime} 52^{\prime \prime} \mathrm{N}, 13^{\circ} 52^{\prime} 37^{\prime \prime} \mathrm{E}\right)$ one day before each experiment and fed with apricot tree shoots.

The photoperiod used in the experiment was 13L : 11D, with the lights coming on at 7:00 a.m. Seven observations of $60 \mathrm{~min}$ each were carried out at each temperature, at the $1^{\text {st }}(7: 00$ a.m.), $3^{\text {rd }}(9: 00$ a.m. $), 5^{\text {th }}(11: 00$ a.m. $), 7^{\text {th }}(1: 00$ p.m. $), 9^{\text {th }}(3: 00$ p.m. $)$, $11^{\text {th }}(5: 00$ p.m. $)$ and $13^{\text {th }}(7: 00$ p.m. $)$ hour of each day. The cages were kept at either $15,20,25,30,35,40$ or $45 \pm 1^{\circ} \mathrm{C}$ and a relative humidity of $50 \pm 5 \%$. The observations at each temperature were replicated eight times for each sex. During each one hour observation period, the number of $5 \mathrm{~min}$ sequences when the insects were stationary was recorded.

The tendency of $C$. tenebrionis adults to cut through the petioles of leaves was used to estimate the rate of feeding, which was based on the number of detached leaves. Feeding activity was determined at the same temperatures and in the same experimental layout, using the same number of replicates and at the same time of day as the measurements of insect movement. Overwintered individuals of $C$. tenebrionis were also used in these experiments.

In order not to disturb the insects, the number of detached leaves were counted at the end of day.

\section{Field experiment}

Measurements of flight activity and meteorological variables were made between May and August 2005, in an aprico orchard approximately $15 \mathrm{~km}$ from Caltanissetta in Sicily (37 $25^{\prime} 52^{\prime \prime} \mathrm{N}, 13^{\circ} 52^{\prime} 37^{\prime \prime} \mathrm{E}$, altitude $500 \mathrm{~m}$ a.s.1.).

The orchard was approximately 10 years old and covered an area of 2 ha and had been organically managed since planting. This area specializes in arboreal production (peach, grape, apricot etc.) and $C$. tenebrionis is abundant.

The trees were arranged in a 4 by $4 \mathrm{~m}$ layout and grown in the form of a vase $2.50 \mathrm{~m}$ high. Observations were carried out once a week and began one hour after dawn. During the day, 7 onehour observations were made, alternating with a pause of one hour on the $1^{\text {st }}, 3^{\text {rd }}, 5^{\text {th }}, 7^{\text {th }}, 9^{\text {th }}, 11^{\text {th }}$ and $13^{\text {th }}$ hour.

The observations on the flight of $C$. tenebrionis adults were made within a unit (observation unit) of 6 plants arranged in two rows of three plants. Each individual observer randomly chose the units to observe and remained outside the unit

A Davis meteorological station (model Vantage Pro $^{\mathrm{tm}}$ ) with temperature (accuracy $\pm 0.5^{\circ} \mathrm{C}$ ), humidity (accuracy $\pm 3 \% \mathrm{RH}$ ) and wind speed (accuracy $\pm 5 \%$ ) sensors was placed at the centre of the observation unit at a height of $1.80 \mathrm{~m}$. The wind vane was placed at the top of the meteorological column.

Wind speed and temperature were measured during each observation. Temperature was measured every $10 \mathrm{~min}$ and wind speed every three minutes. Averages for each hour were calculated. Each flight was recorded and followed until the insect was no longer visible.

On observation days, the density of adult insects was estimated; the estimate was based on examining 12 randomly chosen plants growing outside the observation unit. The flights recorded were of overwintered $C$. tenebrionis. The adults of the new generation appeared in the area of study in the middle of August. Observations made in September and October indicated that newly emerged adults are unable to fly.

\section{Data analysis}

\section{Movement activity of the insect}

In order to stabilize variance, the data were reciprocally transformed using the formula $1 /(n+1)$. Reciprocal transformation is particularly useful in the analysis of reactions to stimuli (Soliani, 2005) such as variations in temperature. With this transformation it is possible to use periods of inactivity of any duration with a maximum value $=1$, which corresponds to continual movement.

Insect movement was evaluated using a factorial ANOVA with temperature, gender and time as the main effect, their interaction (Temperature-Time), (Temperature-Gender), (TimeGender) and the interaction of (Temperature-Gender-Time). Comparison of the means was carried out using the Tukey test $(\mathrm{P}=0.05)$

To detect an association between independent and dependent variables and find the equation that describes the actual data, non linear regression analysis was carried out using Sigmaplot 8.02 (Sigmaplot, 2002). The independent variables, or predictor (time, temperature) and non-transformed dependent variable (mean of sequences of inactivity) were examined. Coefficients of the non linear equation and the relationship between dependent and independent variables were calculated.

Feeding activity

The feeding activity of $C$. tenebrionis was estimated by recording the number of leaves detached, temperature and gender. Then an analysis of variance by ranks was carried out using two criteria of classification: the Friedman Test (Friedman, 1937); this type of non-parametric analysis was used since it was not valid to use the parametric ANOVA test; a Friedman $\chi^{2}$ F test was used for the analysis of gender and temperature, which approximately distributes as $\chi^{2}$ (chi square distribution) with $(\mathrm{k}-1)$ degrees of freedom, where $\mathrm{k}=$ number of factors per treatment. Only after rejecting the null hypothesis multiple comparisons were carried out (on the basis of Bonferroni's test $\mathrm{T}$ ), which identified the treatments that differed. Non-transformed medians and standard errors are plotted on the graph.

\section{Field experiments}

For the study of flight in the field a stepwise multiple linear regression in SPSS 11.0 (SPSS, 2001) was utilized to evaluate the variables that influence this activity. The effects of factors capable of changing the dependent variable (number of flights) were studied, in particular the effect of the independent variables temperature, wind speed, insect density and time of day. The number of flights $(\mathrm{x})$ was normalised by transformation into $[\lg$. nat. $(\mathrm{x}+0.5)]$, which was done before statistical analysis. The independent variable, time the flight occurred, "Time", was taken in ascending order starting with the first observation of the day, which generally coincided with the first hour after dawn. Temperature was expressed in degrees centigrade $\left({ }^{\circ} \mathrm{C}\right)$, wind speed in metres per second $\left(\mathrm{ms}^{-1}\right)$ and the average number of adults present per plant as number of adults tree ${ }^{-1}$. Non transformed counts are plotted on the graphs.

The coefficients of the linear equation and the relationship between the dependent (number of flights) and independent variables (temperature, wind speed, time, insect density) were calculated. 


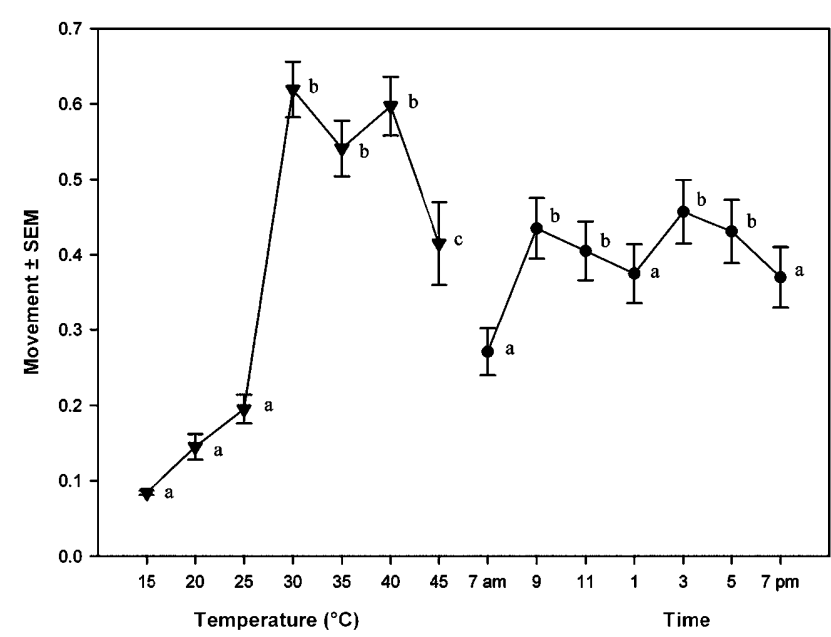

Fig. 1. Trends in mean $( \pm \mathrm{SEM})$ movement $(1 / \mathrm{n}+1) *$ of Capnodis tenebrionis relative to temperature and time of day. Means followed by the same letter are not significantly different at: $(\mathrm{P}=0.05$ Tukey-Kramer Test $) ;{ }^{*}=n$ is the number of $5 \mathrm{~min}$ sequences when inactive.

\section{RESULTS}

\section{Insect movement}

Both temperature $(F=51.88$, df $=6,574 ; \mathrm{P}<0.005)$ and time $(F=4.78, \mathrm{df}=6,574 ; \mathrm{P}<0.005)$ but not gender $(F=0.91, \mathrm{df}=1,574 ; \mathrm{P}>0.05)$ significantly affected movement. There were significant interactions between temperature $*$ time $(F=7.90, \mathrm{df}=36,574 ; \mathrm{P}<0.005)$ and temperature $*$ gender $(F=13.73$, df $=7,574 ; \mathrm{P}<0.005)$. There was no interaction between gender $*$ time $(F=$ 0.09 , df $=7,574 ; \mathrm{P}>0.05)$ and temperature $*$ time $*$ gender $(F=0.09, \mathrm{df}=7,574 ; \mathrm{P}>0.05)$. The incidence of movement was lowest at 15,20 and $25^{\circ} \mathrm{C}$, intermediate at $45^{\circ} \mathrm{C}$ and highest at 30,35 and $40^{\circ} \mathrm{C}$, and also lowest in

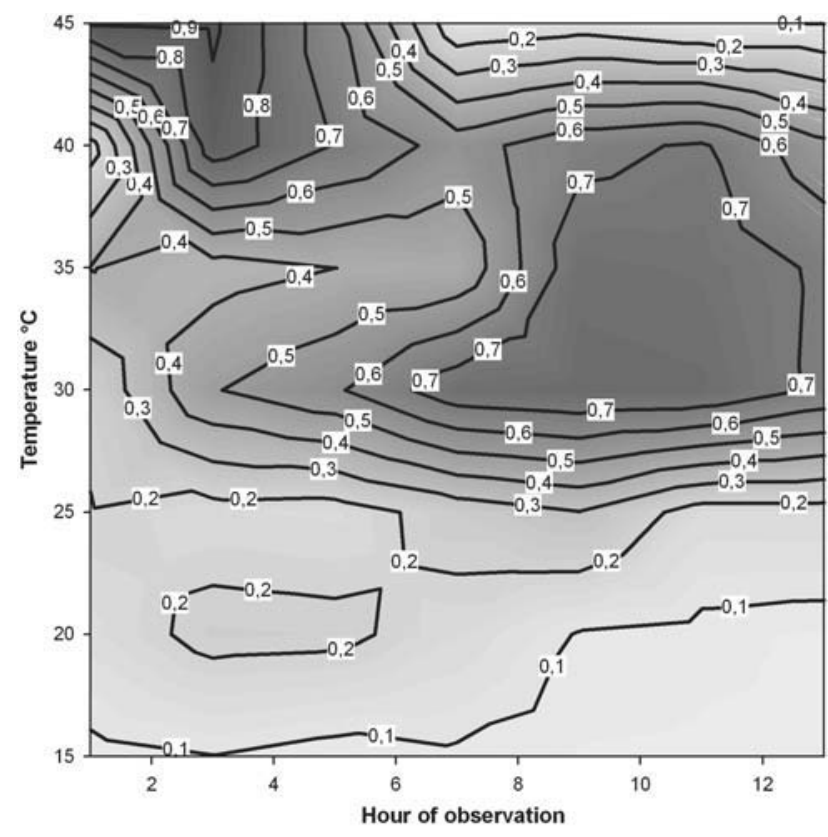

Fig. 2. Incidence of mean observed movement $(1 / n+1) *$ relative to temperature and time. ${ }^{*}=n$ is the number of $5 \mathrm{~min}$ sequences when inactive.

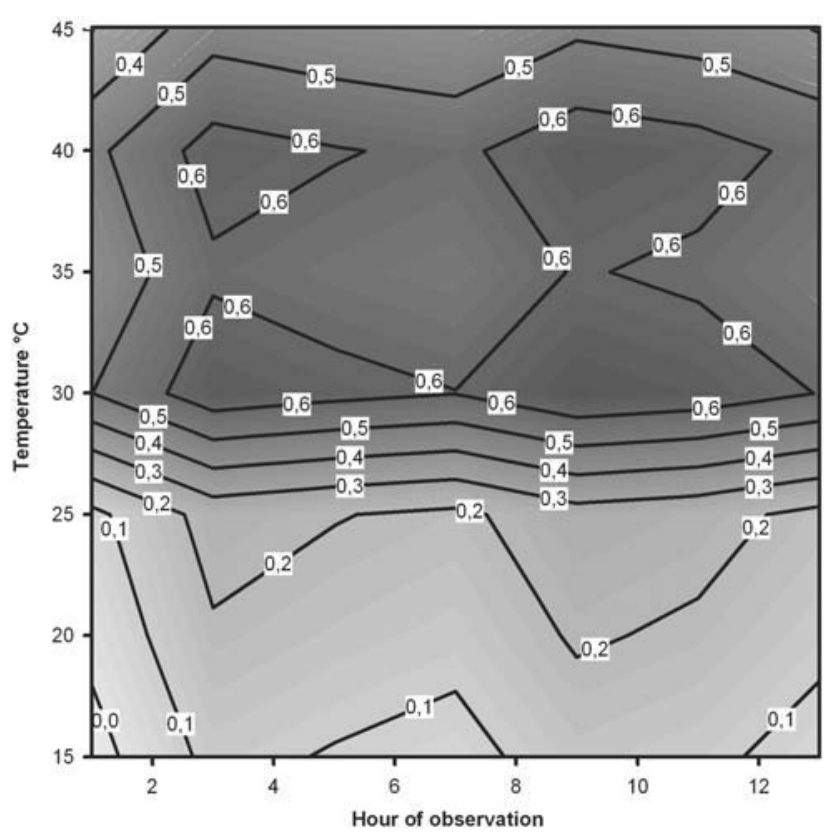

Fig. 3. Incidence of mean expected movement $(1 / \mathrm{n}+1)^{*}$ relative to temperature and time. ${ }^{*}=n$ is the number of $5 \mathrm{~min}$ sequences when inactive.

the $1^{\text {st }}, 7^{\text {th }}$ and $13^{\text {th }} \mathrm{h}$ and highest in the $3^{\text {rd }}, 5^{\text {th }}, 9^{\text {th }}$ and $11^{\text {th }}$ h of observation (Fig. 1).

In order to show the interaction between temperature * time (Figs 2 and 3 ) and temperature * gender (Fig. 4), the means of the results were expressed in terms of incidence of movement. There is a positive interaction between time and temperatures at temperatures above $25^{\circ} \mathrm{C}$ after exposure to these temperatures for $>5 \mathrm{~h}$. It is clear from the graph that temperatures above $40^{\circ} \mathrm{C}$ lead to increased activity only in the first few hours of exposure and then it decreased drastically indicating that temperatures $\leq 45^{\circ} \mathrm{C}$

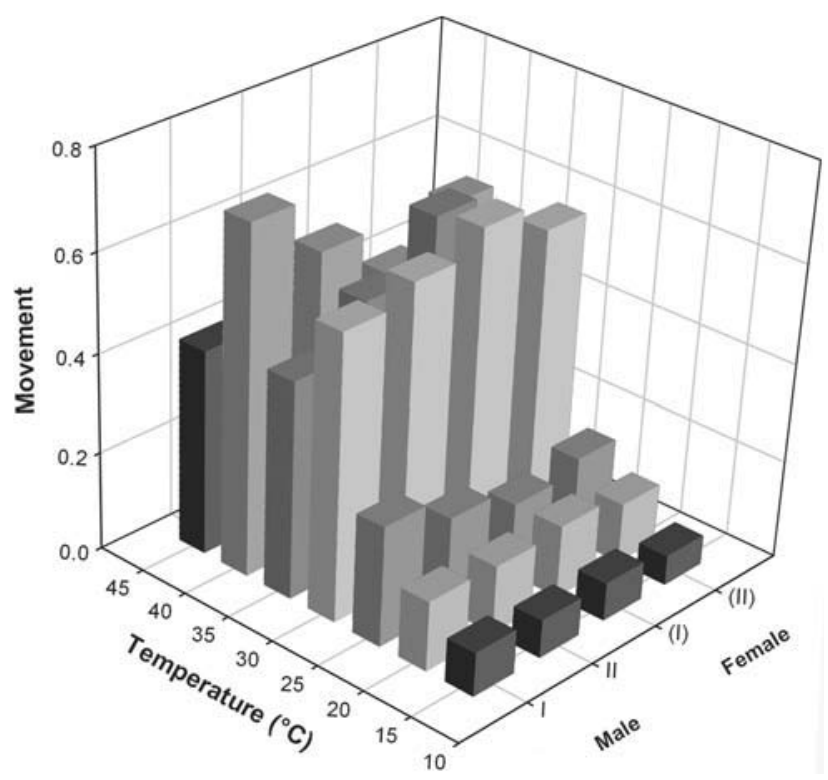

Fig. 4. "Mean observed" I - (I) and "mean expected II - (II) movement $(1 / \mathrm{n}+1)^{*}$ for both sexes and at a range of temperatures. $*=n$ is the number of 5 min sequences when inactive. 
TABLE 1. Coefficient values of the non linear regression equation $\left(\mathrm{f}=\mathrm{y} 0+\mathrm{a}^{*} \mathrm{x}+\mathrm{b}^{*} \mathrm{y}+\mathrm{c}^{*} \mathrm{x}^{2}+\mathrm{d}^{*} \mathrm{y}^{2}\right)$.

\begin{tabular}{crrrr}
\hline & Coefficient & Std. Error & \multicolumn{1}{c}{$\mathrm{t}$} & \multicolumn{1}{c}{$\mathrm{P}$} \\
\cline { 2 - 5 } $\mathrm{x}$ (Time) & & & & \\
$\mathrm{y}$ (Temperature) & & & & \\
Y0 & 33.7643 & 3.1611 & 10.6813 & $<0.0001$ \\
$\mathrm{~A}$ & -0.2965 & 0.3225 & -0.9195 & 0.3629 \\
$\mathrm{~B}$ & -1.9052 & 0.2169 & -8.7833 & $<0.0001$ \\
$\mathrm{C}$ & 0.0337 & 0.0224 & 1.5078 & 0.1387 \\
D & 0.0276 & 0.0036 & 7.7160 & $<0.0001$ \\
\hline
\end{tabular}

inhibit movement in this insect. Interaction between gender and temperature (Fig. 4) is evident in females at temperatures above $25^{\circ} \mathrm{C}$ and $30^{\circ} \mathrm{C}$ for males.

Analysis of the movement using non linear regression indicates associations with independent variables. ANOVA combined with nonlinear regression reveals the acceptability of the regression model, the F test statistic gauges the significance of the independent variables in predicting the dependent variable $(\mathrm{F}=32.846, \mathrm{df}=4.44$; $\mathrm{P}<0.0001$ ).

The value of the multiple correlation coefficient $(\mathrm{R}=$ $0.865)$ and $R$ squared $\left(R^{2}=0.749\right)$, the coefficient of determination, are both high and indicate that the regression model describes the data well.

Regression reveals the equation that best describes the data $\left(f=y 0+a^{*} x+b^{*} y+c^{*} x^{2}+d^{*} y^{2}\right)$. The non linear regression coefficients are presented in Table 1.

In Fig. 5 non linear regression was used to visualize and plot the curve that best describes the shape and behaviour of the data. It is a paraboloid curve.

The results show that the temperature and the time they are exposed to that temperature affect their movement. The highest levels of activity occurred at high mean temperatures of between $30^{\circ} \mathrm{C}$ and $40^{\circ} \mathrm{C}$, and the beetles were less active at low temperatures; at $15^{\circ} \mathrm{C}$ movement is already limited.

\section{Feeding activity}

Feeding activity was most marked between $25^{\circ} \mathrm{C}$ and $40^{\circ} \mathrm{C}$. No feeding was observed at temperatures below $20^{\circ} \mathrm{C}$; there is a noticeable reduction in feeding at temperatures above $40^{\circ} \mathrm{C}$. Furthermore, it appears that in a controlled environment there is no difference in feeding activity between males and females. The Friedman $\mathrm{c}^{2}$ test for the effect of temperature gave values of $\chi_{\mathrm{F}}^{2}=28,7306$ $>20.52 ; \mathrm{P}=0,001 ; \mathrm{df}=6$, of gender $\chi_{\mathrm{F}}^{2}=0.078<0.455$; $\mathrm{P}=0,500 ; \mathrm{df}=1$. There was no change in feeding

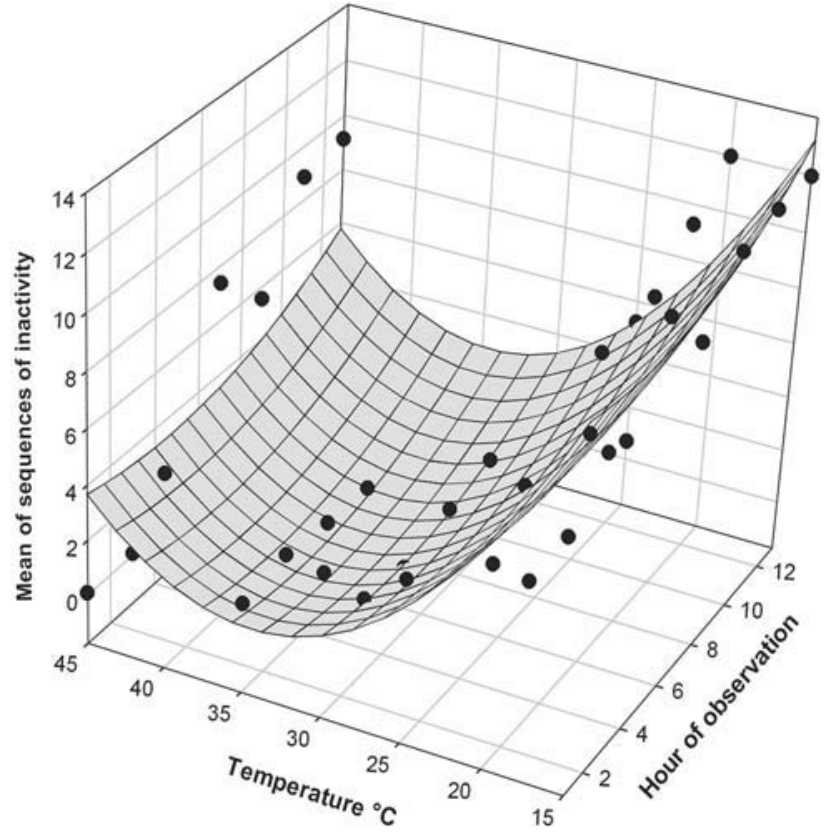

Fig. 5. Mean number of 5 min sequences when inactive and the paraboloid curve that best describes the data.

activity between $25-40^{\circ} \mathrm{C}$ (Fig. 6) but above $40^{\circ} \mathrm{C}$ it declined to values similar to those at $20^{\circ} \mathrm{C}$. No feeding occurred at $15^{\circ} \mathrm{C}$ and little at $20^{\circ} \mathrm{C}$.

\section{Field experiment}

In general, regression realistically models the flight of C. tenebrionis. ANOVA combined with linear regression indicate the acceptability of the regression model from a statistical point of view. The significance of the experimental $\mathrm{F}$ value $(\mathrm{F}=38,149$, $\mathrm{df}=3,139 ; \mathrm{P}<0.0001)$ is greater than the tabular one, which signifies that the variation in flight activity is not random. While ANOVA is a useful test of the ability of the model to explain a certain variation in flight activity, it does not directly indicate the strength of the relationship.

The linear correlation between observed and predicted or expected values of the dependent variable is expressed by the multiple correlation coefficient $(\mathrm{R}=0,672$, $\mathrm{df}=$ $1,139)$, which indicates a close relationship. $\mathrm{R}$ squared, the determination coefficient, the squared value of the multiple correlation coefficient, has a value $\left(\mathrm{R}^{2}=0.452\right)$ that indicates that almost half of the variation in flight activity is explained by the model. A further measure of robustness of the model is the standard error of the estimate, which in this case is relatively small (0.60424).

TABLE 2. Standardized and non-standardized coefficient values. The coefficient for the density variable is not significant and does not contribute to the model.

\begin{tabular}{cccccc}
\hline Variables & Unstandardized Coefficients & Std. Error & Standardized Coefficients Beta & $\mathrm{t}$ & $\mathrm{P}$ \\
\hline (Constant) & $-1,779$ & 0,284 & & $-6,273$ & 0,000 \\
TEMP & 0,112 & 0,011 & 0,675 & 10,135 & 0,000 \\
TIME & 50.67 & 0,013 & $-0,261$ & $-3,847$ & 0,000 \\
WIND & $-0,136$ & 0,036 & $-0,242$ & $-3,731$ & 0,000 \\
DENSITY & Var. excluded & & & 0,203 & 0,839 \\
\hline
\end{tabular}




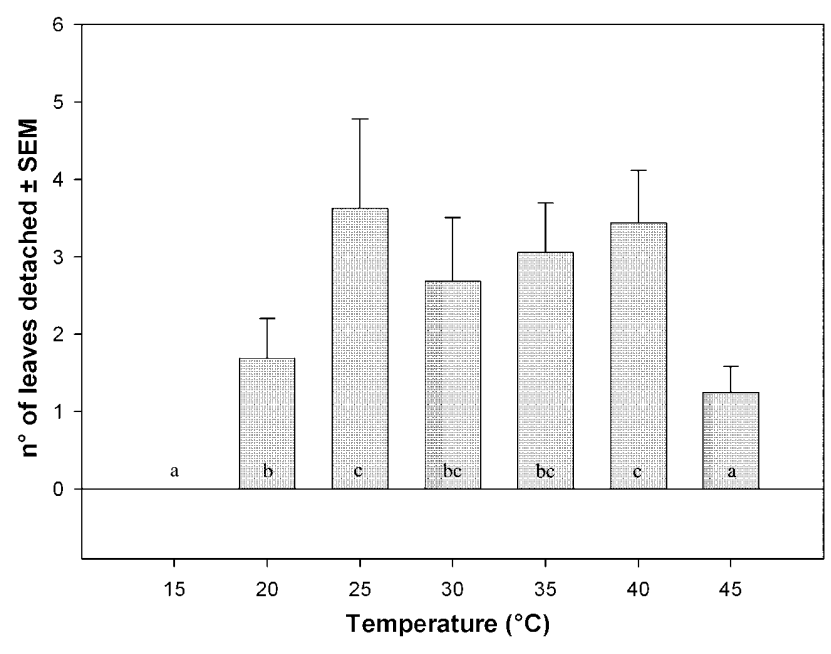

Fig. 6. Median \pm SEM of the feeding activity (no. leaves detached) recorded at different temperatures. Medians followed by the same letter are not significantly different at: $(\mathrm{P}=0.05$ Bonferroni test).

The multiple regression coefficients (unstandardized and standardized) are presented in Table 2.

The validity of the regression model was tested by an analysis of residues and differences between the observed and predicted values of the dependent variable. The assumption of normality was not violated.

In the field, the incidence of flights was positively affected by temperature and negatively by wind and time. Insect density estimated on the day of observation, did not affect the incidence of flight. Fig. 7A and B show the number of flights relative to temperature, wind speed and time of day.

The greatest number of flights occurred at temperatures above $30^{\circ} \mathrm{C}$ and there were no flights at temperatures below $24^{\circ} \mathrm{C}$. Flights occurred most frequently during the middle of the day, when temperatures are highest (Fig. 7
A). Flying activitiy decreases when the temperature falls. No flights were recorded at wind speeds of $>3.5 \mathrm{~ms}^{-1}$ and temperatures lower than $30^{\circ} \mathrm{C}$ (Fig. 7B).

Capnodis tenebrionis was able to take off from any position on a plant, when temperatures were suitable.

Indeed, specimens also took off from the ground although most often it was from the apices of shoots. Flying insects were able to reach heights of up to 15 metres and fly for long distances.

\section{DISCUSSION AND CONCLUSION}

From the experimental results it is evident that $C$. tenebrionis is most active at high temperatures, which possibly accounts for its circum-Mediterranean distribution. In the first half of the $20^{\text {th }}$ century, however, it was also present in Central Europe (Hungary, Slovakia, South Moravia) (Bílý, 2002).

For feeding $25^{\circ} \mathrm{C}$ appears to be the optimum temperature but the incidence of movement at this temperature is very low, or $1 / 3$ of that at $30^{\circ} \mathrm{C}$. Higher levels of both movement and feeding were observed at $30^{\circ} \mathrm{C}$. The laboratory studies of Malagon et al. (1990) indicate that this is also the optimum temperature for egg-laying in C. tenebrionis. As noted by Al Mallah (2003), both in the field and laboratory, Capnodis cariosa also feeds most actively at higher temperatures.

Feeding, like movement, also occurs at $45^{\circ} \mathrm{C}$ early in the day (data not published). However, it is lower than that recorded at $20^{\circ} \mathrm{C}$, and at $45^{\circ} \mathrm{C} \mathrm{C}$. tenebrionis ceased to move after $7 \mathrm{~h}$, but they did not die. C. tenebrionis did not move or feed at $15^{\circ} \mathrm{C}$.

This species, which has always been considered a poor flyer, is at optimal temperatures an adept flyer and can rapidly spread by flight as well as by transport in infested saplings.

In the genus Capnodis, the species cariosa begins flying at $30.7-35.5^{\circ} \mathrm{C}$ (Al Mallah, 2003). These tempera-
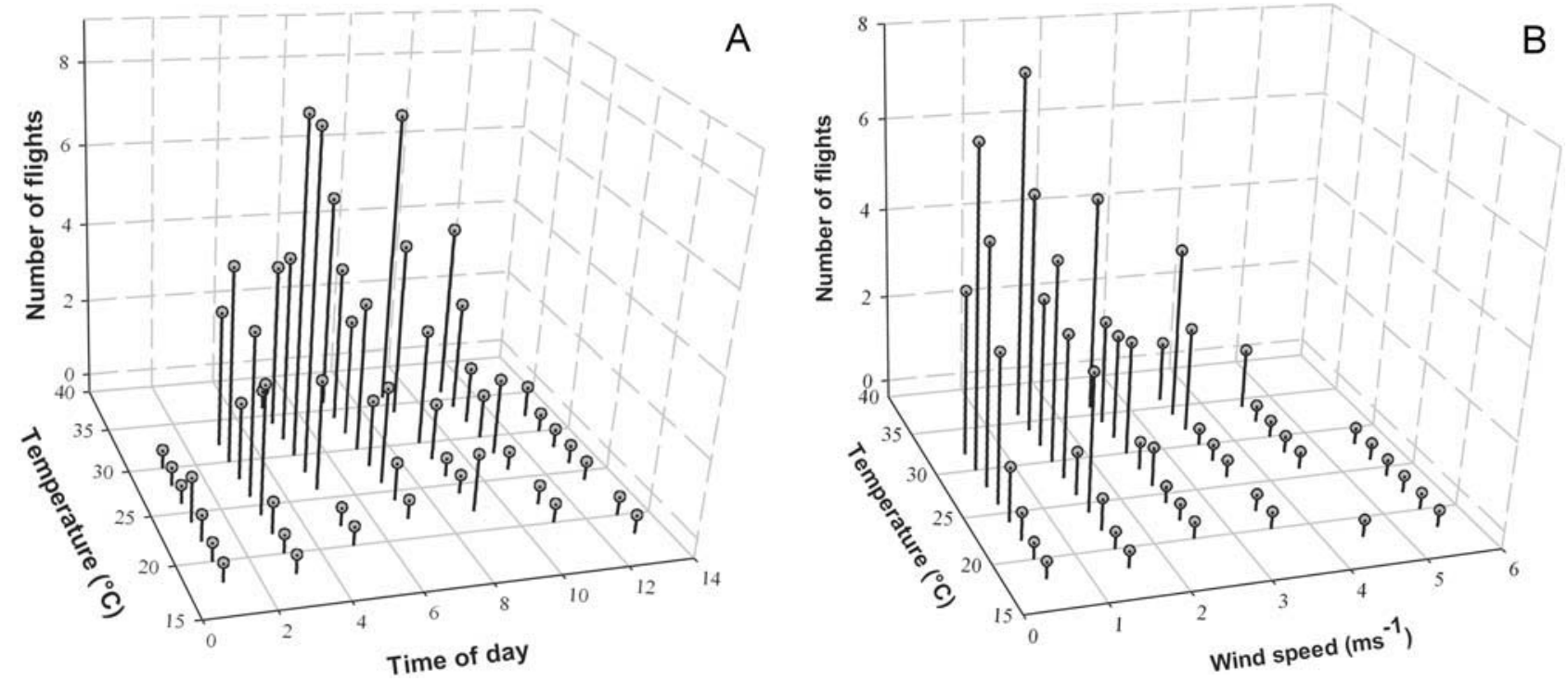

Fig. 7. 3D scatter plots of the number of flights relative to (A) temperature and the time of day (at $1^{\text {st }}, 3^{\text {rd }}, 5^{\text {th }}, 7^{\text {th }}, 9^{\text {th }}, 11^{\text {th }}$ and $13^{\text {th }}$ h) and (B) temperature and wind speed $\left(\leq 0.5 ;>0.5 \leq 1.5 ;>1.5 \leq 2.5 ;>2.5 \leq 3.5 ;>3.5 \leq 4.5 ;>4.5 \leq 5.5 ;>5.5 \mathrm{~ms}^{-1}\right)$. 
tures are higher than those optimum for the take off of $C$. tenebrionis and are likely to influence the distribution of these two species. C. tenebrionis, like other species of Coleoptera, e.g. Trogoderma variabile (Dermestidae) and Rhyzopertha dominica (Bostrichidae) (Wright \& Morton, 1995) and Anthonomus pomorum (L.) (Curculionidae) (Toepfer et al., 2002), exhibits a clear daily flight activity and is diurnal like other Buprestidae, as highlighted by Gray (1974) in Papua New Guinea.

Like C. tenebrionis, other Buprestidae also fly on hot sunny days (Gray, 1974) and in Coroebus rubi L. flight occurs in the warm summer period from the middle of June to the middle of July, depending on location (Kaya \& Kovanci, 2005). Indeed flights are temperature dependent and associated with the rising and setting of the sun, with dispersion primarily linked to the maximum daily temperature. The peak of flight activity occurs in the middle of the day which is also the hottest time. Temperature is also important in determining the flight activity of Ips pines (Say) (Coleoptera: Scolytidae). Indeed, the number of Ips pines collected weekly is temperaturedependent (Aukema et al., 2005), and in spring in Anthonomus pomorum flight activity of overwintered weevils is also temperature dependent (Duan et al., 1998). Obviously other factors, affect the flight activity of $C$. tenebrionis, and as in Lobesia botrana Den. \& Schiff (Hurtrel \& Thiéry, 1999) and Cydia molesta Busck (Lepidoptera: Torticidae) (Hughes \& Dorn, 2002), age, flight experience, mating, etc., are also likely to play a role.

With regard to age the $C$. tenebrionis adults studied had overwintered. Significant differences in flight-initiation responses to ambient temperature are reported for preand postdiapause Colorado potato beetles, Leptinotarsa decemlineata (Voss \& Ferro, 1990a, b) and Anthonomus pomorum (Duan et al., 1998). The differences in the flight ability of pre- and postdiapause adults may be linked to differences in the physiological state of the adults, for example, the sexual maturity of postdiapause individuals. This should be taken into account in monitoring programmes.

As in other Coleoptera (Isard et al., 1999) wind inhibited flight. This is probably linked to the weight and size of C. tenebrionis.

The spread of the species from one orchard to another takes place during the hottest period of the year when locomotory activity is greatest, which accounts for why this species is a potential pest in hot areas of the Mediterranean basin and it is likely $C$. tenebrionis will colonize areas with similar pedo-climatic conditions in the future.

Overall, these studies show that temperature is important in determining a number of vital activities of $C$. tenebrionis and determines their behaviour in the field. Knowing when they disperse within orchards should facilitate the development of an effective monitoring strategy of the overwintered beetle populations in late spring. Furthermore, the timing of the application insecticidal sprays or other control measures should also take into account climatic conditions.
ACKNOWLEDGEMENTS. The author kindly acknowledges the encouragement of V. Vacante, helpful suggestions of $G$. Boiteau and E. De Lillo, technical field assistance of L. Lunetta, and laboratory assistance of F. Manti and I. Foti.

\section{REFERENCES}

Al-Mallah N.M. 2003: Effect of some ecological factors on flight and feeding activity of pistachio stem borer (Capnodis cariosa Pall., Buprestidae: Coleoptera). Arab J. Plant Prot. 21: $123-128$.

AtKinson T.H., Foltz J.L. \& ConNoR M.D. 1988: Flight pattern of phloem- and wood-boring Coleoptera (Scolytidae, Platypodidae, Curculionidae, Buprestidae, Cerambycidae) in a North Florida slash pine plantation. Envir. Entomol. 17: 259-265.

Auerswald L. \& GäDE G. 2002: Physiological and biochemical aspects of flight metabolism in cocoon-enclosed adults of the fruit beetle, Pachnoda sinuate. J. Insect Physiol. 48: 239-248.

Aukema B.H., Clayton M.K. \& RafFa K.F. 2005: Modelling flight activity and population dynamics of the pine engraver, Ips pini Say, in the Great Lakes region: effects of weather and predators over short time scales. Popul. Ecol. 47: 61-69.

Ben Yehuda S., Assaele F. \& Mendel Z. 2000: Improved chemical control of Capnodis tenebrionis and C. carbonaria in stone-fruit plantations in Israel. Phytoparasitica 28: 1-16.

Ben Yehuda S., Assaele F. \& Mendel Z. 2001: Infestation of roots of stone-fruit rootstocks by larvae of two Capnodis species (Buprestidae) and its relation to level of cyanogenic compounds. In: Proceedings of the IOBC-WPRS Fifth International Conference on Integrated Fruit Protection, Lleida, Spain, 22-26 October, 2000. Bulletin OILB-SROP 24(5): 91-95.

BíLÝ S. 2002: Summary of the bionomy of the Buprestid beetles of Central Europe. Acta Entomol. Mus. Nat. Prag. (Suppl.) 10: $48-49$.

Duan J.J., Weber D.C. \& Dorn S. 1998: Flight behaviour of pre- and postdiapause weevils in relation to ambient temperature. Entomol. Exp. Appl. 88: 97-99.

DunN J.P., Kimmerer T.W. \& Nordin G.L. 1986: The role of host tree in attack of white oaks by twolined chestnut borer, Agrilus bilineatus (Weber) (Coleoptera: Buprestidae). Oecologia 70: 596-600.

Elliot N.C., Kieckhefer R.W. \& Beck D.A. 2000: Adult coccinellid activity and predation on aphids in spring cereals. Biol. Control 17: 218-226.

Evans W.G. 1966: Perception of infrared radiation from forest fire by a Melanophila acuminata De Geer (Coleoptera: Buprestidae). Ecology 47: 1061-1065.

Fassotte C. 1999: The pear buprestid, Agrilus sinuatus Olivier, a resurgent pest of our fruit tree crops. Fruit Belge 67: 45-50.

Ferro D.N., Alyokhin A.V. \& Tobin D.B. 1999: Reproductive status and flight activity of the overwintered Colorado potato beetle. Entomol. Exp. Appl. 91: 443-448.

Friedman M. 1937: The use of ranks to avoid the assumption of normality implicit in the analysis of variance. J. Am. Statist. Assoc. 32: 675-701.

GarRido A. 1984: Bioecologia de Capnodis tenebrionis L. (Col. Buprestidae) y orientaciones para su control. Bol. Sanid. Veget. Plagas 10: 205-221.

GRAY B. 1974: Observations on insect flight in a tropical forest plantation. V. Flight activity of Buprestidae and Othniidae (Coleoptera). Z. Angew. Entomol. 76: 190-195.

Groot DE P. \& NotT R.W. 2003: Response of Monochamus (Col., Cerambycidae) and some Buprestidae to flight intercept traps. J. Appl. Entomol. 127: 9-10, 548-552. 
Hughes J. \& Dorn S. 2002: Sexual differences in the flight performance of the oriental fruit moth, Cydia molesta. Entomol. Exp. Appl. 103: 171-182.

Hurtrel B. \& ThiÉRY D. 1999: Modulation of flight activity in Lobesia botrana Den. \& Schiff. (Lepidoptera: Tortricidae) females studied in wind tunnel. J. Insect Behav. 12: 199-211.

Isard S.A., Nasser N.A., Spencer J.L. \& Levine E. 1999: The influence of the weather on western corn rootworm flight activity at the borders of a soybean field in east central Illinois. Aerobiologia 15: 95-104.

Kaya M. \& Kovanci B. 2005: Investigation on the adult population fluctuations of Coroebus rubi L. (Coleoptera: Buprestidae) on raspberry in Bursa province in Turkey. Tarim Bilimleri Dergisi 11: 142-146.

Malagon J., Garrido A., Busto T. del \& Castaner M. 1990: Influence of some abiotic factors on the oviposition of Capnodis tenebrionis (L.) Coleoptera, Buprestidae. Investig. Agr. Prod. Prot. Veget. 5: 441-446.

Marannino P. \& de Lillo E. 2005: Nemici naturali di Capnodis tenebrionis (L.) (Coleoptera: Buprestidae) ed effetto dell'umidità del suolo sulla schiusura delle uova. $X X$ Congresso Nazionale Italiano di Entomologia, Assisi, 13-18 Giugno. $233 \mathrm{pp}$.

Markalas S. \& Kalapanida M. 1997: Flight pattern od some Scolytidae attracted to flight barrier traps baited with ethanol in an oak forest in Greece. Anz. Schädlingsk. 70(3) 55-57.

Martin P., Soria F.J., Villagran M. \& Ocete M.E. 1998: Food preference of the adult of Capnodis tenebrionis L. (Coleoptera: Buprestidae) for six plant species in the laboratory. Bol. Sanid. Veget. Plagas 24: 107-112.

MiLLER D.R. 2006: Ethanol and (-)- $\alpha$-pinene: attractant kairomones for some large wood-boring beetles in Southeastern USA. J. Chem. Ecol. 32: 779-794

Morewood W.D., Hein K.E., Katinic P.J. \& Borden J.H. 2002: An improved trap for large wood-boring insects, with special reference to Monochamus scutellatus (Coleoptera: Cerambycidae). Can. J. Forest Res. 32: 519-525.

Muirhead J.R., Leung B., van OverdiJK C., Kelly D.W., Nandakumar K., Marchant K.R., Macisaac H.J. 2006: Modelling local and long-distance dispersal of invasive emerald ash borer Agrilus planipennis (Coleoptera) in North America. Divers. Distrib. 12: 71-79.

Oliver J.B., Fare D.C., Youssef N. \& Klingeman W. 2003: Collection of adult flatheaded borers using multicoloured traps. Proceedings of the $48^{\text {th }}$ Annual SNA Research 5: 193-196.

Perez Mendoza J., Hagstrum D.W., Dover B.A., Hopkins T.L. \& BAKER J.E. 1999: Flight response, body weight, and lipid content of Rhyzoperta dominica (F) (Coleoptera: Bostrichidae) as influenced by strain, season and phenotype. J. Stor. Prod. Res. 35: 183-196.

Schimtz H. \& Bleckmann H. 1998: The photomechanic infrared receptor for the detection of forest fires in the beetle Melanophila acuminata (Coleoptera: Buprestidae). J. Comp. Physiol. (A) 182: 647-657.

Schmitz H., Schmitz A. \& Bleckmann H. 2000: A new type of infrared organ in the Australian "fire-beetle" Merimma atrata (Coleoptera: Buprestidae). Naturwissenschaften 87: 542-545.

Schmitz H., Schmitz A., Trenner S. \& Bleckmann H. 2002: A new type of insect infrared organ of low thermal mass. Naturwissenschaften 89: 226-229.

SIGMAPLOT 2002: Sigmaplot for window version 8.02. SPSS Inc.

Soliani L. 2005: Statistica Univariata e Bivariata Parametrica e Non Parametrica per le Discipline Ambientali e Biologiche. Uni.Nova, Parma, http://www.dsa.unipr.it/soliani

SPSS 2001: SPSS 11.0 version for window. SPSS, Chigago, IL.

ToEpfer S., Gu H. \& Dorn S. 2002: Phenological analysis of spring colonisation of apple trees by Anthonomus pomorum. Entomol. Exp. Appl. 103: 151-159.

Voss R.H. \& FERRo D.N. 1990a: Ecology of migratine Colorado potato beetle (Coleoptera: Chrysomelidae) in western Massachusetts. Envir. Entomol. 19: 123-129.

Voss R.H. \& FERro D.N. 1990b: Phenology of flight and walking by Colorado potato beetle (Coleoptera: Chrysomelidae) adults in western Massachusetts. Envir. Entomol. 19: 117-122.

Wright E.J. \& Morton R. 1995: Daily flight activity of Trogoderma variabile (Coleoptera: Dermestitidae) and Rhizoperta dominica (Coleoptera: Bostrichidae). J. Stor. Prod. Res. 31: 177-184.

Zera J.A., Sall J. \& Otтo K. 1999: Biochemical aspects of flight and flightlessness in Gryllus: Flight fuels, enzyme activities and electrophoretic profiles of flight muscles from flight-capable and flightless morphs. J. Insect Physiol. 45: 275-285.

Received July 13, 2006; revised and accepted December 27, 2006 